\title{
Measuring and Meeting Service Quality in Professional Accounting Services
}

\author{
Noor Adwa Sulaiman ${ }^{1}$ and Zarina Zakaria
}

\begin{abstract}
The objective of this paper is to assess the service quality of management advisory services offered by accounting firms in Malaysia. The SERVQUAL technique is used to identify the gap between the expectations and perceptions of customers on the actual service received. The quality function deployment technique is then used to identify elements that can be improved to meet customer expectations and address the quality gap in MAS. The results of this study show that there is an overall service quality gap perceived by the customers. Thus, improvements are required across all four service quality dimensions (credibility, competence, responsiveness and reliability). The results also identify several key elements of improvement that should be focused on by the accounting firms to meet customer expectations and narrow the service quality gap.
\end{abstract}

Keywords: SERVQUAL, QFD, Gap Analysis, Management Advisory Services

\section{Introduction}

Management advisory services (MAS) are recognized as part of the professional services offered by accounting firms (Thompson et al., 1997; Briloff, 1994). McKell and Stock (1987) highlight that MAS in most accounting firms are growing rapidly and becoming a very important area of specialty. This is evident by the fact that less than $25 \%$ of accounting firms provide traditional corporate accounting and auditing services while the majority perform other professional services (Asohan, 2002). Revenue generated from these professional services has increased over the past decade (Turner et al., 1999). The accounting firms have a received high profit margin from these professional services (Houston et al., 2005). Teoh and Lim (1996) indicate that consultancy fees made up at least 20 to 30 per cent of the total revenue of accounting firms in Malaysia and that the trend is likely to increase. The study by Foong (2002) shows that the fee income

$1 \quad$ Corresponding author: Dr Noor Adwa Sulaiman is a Lecturer at the Faculty of Business \& Accountancy, University of Malaya, email: adwa@um.edu.my. Dr Zarina Zakaria is a Senior Lecturer at the Faculty of Business \& Accountancy, University of Malaya. 
from professional services contributed about 42.5 per cent of the revenue for accounting firms in Malaysia.

The increasing importance and growth in MAS may suggest that accounting firms are operating in a more competitive market. Consequently, accounting firms need to formulate strategies to be competitive and remain in the industry. The professional service firms need to place more emphasis on aspects of service quality and re-examine their strategies to gain a competitive advantage (Cameran et al., 2010; Welsh and Dey, 2002; Lee et al., 2000).

Prior research has shown that accounting firms have diversified their types of service and that the importance of MAS is well recognized (Türk and Avcilar, 2009, p.37; Turner et al., 1999). Nevertheless, research on the assessment of quality in MAS is limited. As a result, little is known about the level of service quality of MAS offered by accounting firms in Malaysia. Specifically, there is a dearth of empirical research focusing on assessing and meeting the service quality in MAS. This study attempts to fill the gap by employing the service quality model by Turner et al. (1999) to examine customer perceptions and expectations of service quality in MAS, and to identify strategies that should be implemented by the service provider to fulfil the expectations of customers. Specifically, the objectives of the study are:

- $\quad$ To assess the service quality of MAS offered by accounting firms in Malaysia by analysing customer expectations and perceptions of service quality using the SERVQUAL technique.

- $\quad$ To identify the expectations of service quality dimensions and attributes most important to customers of MAS.

- To determine the most competitive elements of improvement to meet the expectations of customers through the use of the quality function deployment (QFD) technique.

The remainder of this paper is organised as follows. In the next section prior literature related to this study is examined. Section 3 describes the research framework and the approach used for collecting and analysing the data. The results and discussion are presented in Section 4. The final section provides a conclusion to the study.

\section{Literature Review}

Parasuraman et al. $(1988 ; 1985 ; 1991)$ introduced the SERVQUAL technique to measure service quality that encompassed five service quality dimensions (assurance, empathy, tangible, reliability and responsiveness). The service quality model measures service quality by analysing the difference between customer expectations and perceptions in a form of gap score. The SERVQUAL 'gap 
analysis' provides direct attention to the organisation of service quality issues and shortfalls that can have an impact on service quality. It also enables one to determine the relative importance of service quality features that constitute service quality. This technique is recognized as one of the most widely used techniques to measure quality in service firms (Baki et al., 2009).

The service quality model has been widely acknowledged and applied in various service settings including accounting, health care, and education services (Abili et al., 2012; Cameran et al., 2010; Ismail et al., 2006; Baldwin and Sohal, 2003; Brysland and Curry, 2001). The application of the service quality model to accounting research, particularly MAS, only started in late 1990. Turner et al. (1999) found that the SERVQUAL model is viable for assessing service quality in MAS. In their study, the descriptive and statistical results indicated that a 13-item scale was significantly associated with clients' perceptions of service quality (secure, trust, ethical, protect, understood, company knowledge, industry knowledge, prompt, willing, respond, promise, depend and right). The later study by Aldhizer et al. (2002) shows that the service quality model proposed by Turner et al. (1999) is valid and reliable in measuring the service quality of MAS.

Turk and Avcilar (2009) show that the SERVQUAL scale is able to measure the service quality of audit firms in Istanbul satisfactorily. They identify assurance as the most important service quality dimension, which is followed by reliability, responsiveness, empathy and tangible. The study by Ismail et al. (2006) in Malaysia identifies the service quality gap in audit services in four main areas: empathy, reliability, assurance and responsiveness of the audit firms. They also determine that customers of audit services expect accounting firms to be more reliable, be able to convey trust and confidence and be more responsive to assist their clients.

While SERVQUAL solely identifies which service quality feature is the most important or significant, several techniques have been applied to a service or product design in prior research to rank the importance of these service quality features. One of the popular techniques used is the QFD technique, which is an intermediary tool to translate customer expectations into the business process (Andronikidis et al., 2009; Jeong and Oh, 1998; Ballantyne et al., 1995). Yoji Akao introduced the concept of QFD in Japan in 1966, as a strategy that assesses quality that is built into products or services (Hauser and Clausing, 1988). The main purpose of QFD is to translate customer requirements into a logical matrix system to determine the most important requirements and how best to utilise the available company resources to meet those needs. It translates customer requirements into appropriate organizational requirements. The QFD enables a link to be made between service quality expectations and the business processes that contribute to fulfilling them. It has been widely used in the service sector like public services, higher education, health care and telecommunications (Baki 
et al., 2009; Yeşilada and Yurdakul, 2009; Hwarng and Teo, 2001; Curry, 1999; Kim et al., 1997; Radharamanan and Godoy, 1996), whereby QFD has been shown to improve the existing services.

\section{Methodology}

This section provides a brief overview of the research methodology used in this study.

\subsection{Sample}

Data were gathered using a postal questionnaire. A questionnaire was used as it has the advantage of being simple to administer and easy to tabulate and analyse (Burns and Bush, 2000). Prior to the actual collection of the data, the questionnaire was pre-tested with a convenience sample of 30 financial controllers of public listed companies. In addition, comments and suggestions from 5 academics were also gathered. This was to clarify the potential areas of misinterpretation, and administration and data scanning issues. Minor changes were made before conducting the actual study.

Two sample groups of respondents were used to achieve the objectives of this study; namely, financial controllers as customers of MAS and accounting firms as service providers of those services. The first group of respondents comprised financial controllers of companies listed on Bursa Malaysia that received MAS from the accounting firms. The respondents were selected on the basis of the degree of involvement in engaging accounting firms for MAS. The second group of respondents was managing partners of the accounting firms. They were chosen based on their expertise and involvement in providing advisory services. Their opinion, ideas and suggestions were sought to identify customer expectations of MAS while considering all the aspects of resources they have including technical, cost and reliability aspects.

The data were obtained from two separate stages of related studies. The first study involved the process of obtaining and then comparing the scores for the financial controller perceptions and expectations of quality so as to measure the service quality of MAS by using the SERVQUAL technique. Then, in the second study, the QFD technique was used to identify the elements that can be improved from the point of view of the managing partners that would meet the customer or financial controllers' expectations concerning service quality, and to address any service quality gap identified in the first study.

In October 2008, questionnaires were mailed to 500 financial controllers of public companies listed in Malaysia; 75 respondents (15\% response rate) returned the questionnaire. Whilst a relatively low response rate was achieved, the rate nevertheless equates favourably in terms of aggregate responses with two similar studies. First, the study by Turner et al. (1999) reported an $8 \%$ usable response 
rate. Second, a study carried out by Aldhizer et al. (2002) reported a 12\% usable response rate. All 75 respondents engaged Big four accounting firms to provide their consulting services. For this reason only Big four accounting firms were included in the sample for the second stage of the study. Questionnaires were mailed to 20 partners, yielding a $20 \%$ response rate.

\subsection{Research Instruments}

In the first stage of the study a structured questionnaire was used. This was adopted based on the service quality model proposed by Turner et al. (1999), and was divided into two sections. Section A was divided into two parts. Part I consisted of questions concerning customer perceptions of the service quality of MAS pertaining to the overall assessments or evaluations of customers of the actual service quality they received. The instrument used was a five-point Likerttype scale to determine the level of agreement with each statement, whereby 1 denotes strong disagreement with the service quality statement and 5 very strong agreement with the service quality statement.

Part II consisted of questions on customer expectations concerning the service quality that customers expect when utilising MAS. The instrument utilised is a five-point Likert-type scale to determine the level of importance of each statement, whereby 1 denotes the least important and 5 the most important service quality characteristics or attributes to the clients. Section A was designed to identify any gap in the service quality of MAS, as perceived by the customers. Section B consists of questions concerning the demographic information of the respondents.

The second stage of the study used a structured questionnaire with openended questions assigned to the service providers of MAS. The questionnaire was divided into three parts. Part I outlined the service quality expectations by customers of MAS based on the first stage of the study (Section A, Part II - Expectation Section); service providers were then asked how to meet these expectations. The aim of this section was to derive ideas for improvement or strategies in order to meet customer expectations; no limit was set for the number of improvements suggested. A rule of the thumb is to expect at least twice the number of customer requirements (Guinta and Praizler, 1993). Thus, respondents were required to propose two elements of improvement for each customer requirement.

Part II involved rating the ease of implementing the elements of improvement identified by accounting firms to meet the customer requirements. The instrument used was a five-point Likert scale to determine the level of ease of implementation with 1 denoting least easy and 5 denoting the most easy to implement. Part III involved service providers' perceptions concerning the achievability of customer requirements through adopting the proposed strategies. This shows the relationship between customer requirements and the elements of improvement 
identified while taking into consideration the technical, cost and reliability resources from the point of view of the service providers. Section B consisted of questions concerning the demographic information of the respondents.

\subsection{Application of SERVQUAL}

SERVQUAL defines service quality as a function of the gap between customer expectations of a service and their perceptions of the actual service delivered by the organization (Parasuraman et al., 1988). "Perceptions" refer to the customers' evaluation of the service provider. "Expectations" are the requirements of customers, which is what they feel a service provider should offer. This instrument requires respondents to complete a series of scales that measure their expectations of a particular company in respect of a wide array of specific service issues. Subsequently, they are asked to record the perceptions of that company's performance concerning those same characteristics. When perceived performance ratings are lower than expectations, this is a sign of poor quality; the reverse indicates good quality. For assessing the service quality of MAS, the mean and standard deviation scores for each item were calculated for the perception level and the expectation level. The mean perception scores were compared to the mean expectation scores for the various service quality dimensions and attributes so as to identify the gap score. The gap measures how effectively the service provided compares with the service expected. If this gap is zero or positive, the clients' expectations have been matched or exceeded. However, if the gap is negative, there is a service delivery shortfall in the eyes of the client. The service quality gap was computed for each statement or attribute and dimension, giving a good indicator of any service deficiency.

\subsection{Application of QFD}

For the purpose of this study, the QFD technique was adopted according to Sahney et al. (2003). The application is explained as follows:

(1) The questionnaires comprised a set of questions, wherein the respondents (managing partners) were asked to rate on a scale of five (from high to low), the level of importance they assigned to each of the customer expectations.

(2) Then for each statement, the degree of importance of customer expectations was calculated according to the equation as stated below:

$$
\begin{gathered}
\mathrm{Cj}=\mathrm{i}={ }_{1}^{5} \text { Sixfij } \\
\hline \mathrm{i}={ }_{1}^{5} \operatorname{Sixfij}
\end{gathered}
$$$$
\text { Equation (1) }
$$

Where, $\mathrm{i}=$ category value $(\mathrm{i}=1,2, \ldots . .5)$.

$f=$ response to category $\mathrm{i}$ of question $\mathrm{j}$.

$\mathrm{Cj}=$ average category of question $\mathrm{j}$. 
(3) Each respondent was then asked to identify strategies or elements of improvement to meet customer expectations (identified in Step 1).

(4) Then each respondent was asked to relate each of the customer requirements (Step 1) with each of the items identified in Step 3 (strategies or elements of improvement). The relationship was categorised in terms of strong, moderate or weak and expressed by using integers 5, 3 and 1 to determine the service providers' perception of the achievability of each of the elements of improvement proposed to meet each of the customer requirements.

(5) Now, for each statement of the degree of importance of customer expectations (Step 2) was multiplied by the quantified relationship - strong, moderate or weak relationship (Step 4). This gave appropriate weightage to individual elements of improvement.

(6) The values calculated in step 5 were finally averaged and these were then added to arrive at the absolute and relative rankings of the elements of improvement. These values were adjusted based on the weight for ease of implementation assigned for each improvement element to derive the final relative score.

(7) The different improvement elements with an alpha value of more than 0.60 were computed, correlated and then plotted as (.) on the roof of the house of quality (see Figure 1). The correlated pairs were identified.

\section{Results and Discussion}

This section describes in greater detail the findings of this study.

\subsection{Demographic Characteristics of the Respondents}

Table 1 shows the frequencies and percentages of the demographic characteristics of the respondents. Males represent the majority of the financial controllers, accounting for 51 persons. Among the 75 respondents, the majority of them $(68 \%)$ are in the range of 41 to 50 years old. About $20 \%$ are in the age range of 31 to 40 years old and $12 \%$ are aged 50 years old and above. In comparison, the majority of the managing partners are male (75\%) and aged between 41-50 years old $(75 \%)$.

The range of respondents' experience in the present company is categorised into four groups. About $25 \%$ of the financial controllers have more than 10 years experience, $27 \%$ in the range of 3 to 6 years, $19 \%$ less than 3 years and $29 \%$ in the range of 7 to 10 years. The majority of the financial controllers have experience in the present position of between 3 to 6 years (45\%), $23 \%$ of more than 10 years; nearly $15 \%$ have less than 3 years and $17 \%$ between 7 to 10 years. With regards to the highest education qualification attained, the majority of the respondents (69\%) have professional qualifications (e.g. ACCA and CIMA), $11 \%$ hold a Master/PhD and $20 \%$ have a bachelor degree. All managing partners 
possess professional qualifications with the majority having more than 10 years experience in the present company and position.

Table 1: The Demographic Characteristics of the Respondents

\begin{tabular}{|c|c|c|c|c|}
\hline & \multicolumn{2}{|c|}{ Financial Controllers $(n=51)$} & \multicolumn{2}{|c|}{ Managing Partners $(n=20)$} \\
\hline Characteristics & Frequency & Percentage $(\%)$ & Frequency & $\begin{array}{c}\text { Percentage } \\
(\%)\end{array}$ \\
\hline $\begin{array}{l}\text { Gender: } \\
\text { Male } \\
\text { Female }\end{array}$ & $\begin{array}{l}51 \\
24\end{array}$ & $\begin{array}{l}68 \\
32\end{array}$ & $\begin{array}{c}15 \\
5\end{array}$ & $\begin{array}{l}75 \\
25\end{array}$ \\
\hline Total & 75 & 100 & 20 & 100 \\
\hline $\begin{array}{l}\text { Age: } \\
\text { Below } 30 \\
31-40 \\
41-50 \\
50 \text { and above }\end{array}$ & $\begin{array}{c}- \\
15 \\
51 \\
9\end{array}$ & $\begin{array}{c}- \\
20 \\
68 \\
12\end{array}$ & $\begin{array}{c}- \\
2 \\
15 \\
3\end{array}$ & $\begin{array}{c}- \\
10 \\
75 \\
15\end{array}$ \\
\hline Total & 75 & 100 & 20 & 100 \\
\hline $\begin{array}{l}\text { Years of experience in } \\
\text { present company: } \\
\text { < } 3 \text { years } \\
3-6 \text { years } \\
7-10 \text { years } \\
>10 \text { years }\end{array}$ & $\begin{array}{l}14 \\
20 \\
22 \\
19\end{array}$ & $\begin{array}{l}19 \\
27 \\
29 \\
25\end{array}$ & $\begin{array}{l}3 \\
5 \\
6 \\
6\end{array}$ & $\begin{array}{l}15 \\
25 \\
30 \\
30\end{array}$ \\
\hline Total & 75 & 100 & 20 & 100 \\
\hline $\begin{array}{l}\text { Years of experience in } \\
\text { present position: } \\
\text { < } 3 \text { years } \\
3-6 \text { years } \\
7-10 \text { years } \\
>10 \text { years }\end{array}$ & $\begin{array}{l}11 \\
34 \\
13 \\
17\end{array}$ & $\begin{array}{l}15 \\
45 \\
17 \\
23\end{array}$ & $\begin{array}{l}2 \\
5 \\
6 \\
7\end{array}$ & $\begin{array}{l}10 \\
25 \\
30 \\
35\end{array}$ \\
\hline Total & 75 & 100 & 20 & 100 \\
\hline $\begin{array}{l}\text { Highest education: } \\
\text { Professional } \\
\text { Qualification } \\
\text { Degree (bachelor) } \\
\text { Master/PhD } \\
\text { Others }\end{array}$ & $\begin{array}{c}52 \\
15 \\
8 \\
-\end{array}$ & $\begin{array}{c}69 \\
20 \\
11 \\
-\end{array}$ & $\begin{array}{c}20 \\
- \\
- \\
-\end{array}$ & $\begin{array}{c}100 \\
- \\
- \\
-\end{array}$ \\
\hline Total & 75 & 100 & 20 & 100 \\
\hline
\end{tabular}




\subsection{SERVQUAL Results}

This section describes the findings of the first stage of the study, which is to assess the level of quality of MAS and to identify the service quality dimensions and attributes that are expected by customers of MAS. Two software packages - SPSS 14 version and Microsoft Excel were used for the analysis of the data. The reliability of the scale for assessing customer perceptions and expectations of service quality was assessed by calculating the Cronbach's alpha for both the perception and expectation dimensions. The coefficient a values for the perception sub-scales range from 0.728 to 0.852 while those for the expectation sub-scales range from 0.746 to 0.901 (see Table 2), indicating that the scale is internally consistent (Cronbach, 1951). Table 2 lists the mean scores of the expectation and perception scales for each of the four service quality dimensions and the mean gap score.

Table 2: Mean levels of customer perceptions and expectations, standard deviation, Cronbach's alpha and service gaps for each dimension

\begin{tabular}{|l|c|c|c|c|c|}
\hline Dimension & $\begin{array}{c}\text { Mean } \\
\text { levels of } \\
\text { customer } \\
\text { perception }\end{array}$ & $\begin{array}{c}\text { Standard } \\
\text { deviation / } \\
\text { Cronbach's } \\
\text { alpha }\end{array}$ & $\begin{array}{c}\text { Mean levels } \\
\text { of customer } \\
\text { expectation }\end{array}$ & $\begin{array}{c}\text { Standard } \\
\text { deviation / } \\
\text { Cronbach's } \\
\text { alpha }\end{array}$ & $\begin{array}{c}\text { Gap } \\
\text { Score }\end{array}$ \\
\hline Credibility & 3.78 & $1.833 / 0.728$ & 4.04 & $1.912 / 0.746$ & -0.26 \\
Competence & 3.48 & $1.759 / 0.761$ & 4.06 & $1.621 / 0.901$ & -0.58 \\
Responsiveness & 3.73 & $1.562 / 0.804$ & 4.06 & $1.244 / 0.761$ & -0.33 \\
Reliability & 3.65 & $1.702 / 0.852$ & 4.07 & $1.579 / 0.826$ & -0.42 \\
\hline
\end{tabular}

The findings from the customer perception section reveal that customers appear to value consultants who are credible (trustworthy and act ethically). This finding is in agreement with those of Turner at al. (1999), and Aldhizer et al. (2002), who show that customers of MAS perceive the Big 4 accounting firms as being highly credible. This study shows that the customers also perceive the accounting firms as being responsive (ready to respond and give prompt service). In comparison, the customers rate service quality as low, which relates to the competence dimension. This result is consistent with that of Weekes et al. (1996) who found that customers of accounting firms in the US perceive accounting firms to be lacking in the competence dimension. However, this is not in agreement with Turner et al. (1995) whose findings show that customers of MAS perceive accounting staff as highly competent.

Although a high perception of quality of services rendered by accounting firms is detected in the perception section, prior expectations of the same services were even higher. From the results obtained, it can be observed that the most 
important of the four dimensions expected by customers is "reliability" (in which the consultant delivers the agreed service in an accurate manner as promised). This result is consistent with Ismail et al. (2006), and Aldhizer at al. (2002), who, based on the findings, conclude that reliability is the most significant service quality dimension expected by customers from consulting firms. In this study, "competence" and "responsiveness" are considered as the second most important dimensions expected by the customers. As shown in Table 2, both dimensions carry the same weight of importance (4.06) and slightly lower than the mean for the expectation of "reliability" dimension (4.07). "Credibility" is considered to be of lower importance with a mean score of 4.04. The customers' choices clearly shows that "reliability", "competence" and "responsiveness" are the most critical dimensions of service quality expected by them.

The means of the perception responses for the four dimensions range from 3.48 to 3.78 while the mean expectation responses for the four dimensions range from 4.04 to 4.07. Analysis of the gap scores shows a range among the dimensions from -0.26 to -0.58 . Table 2 shows that the gap score calculated for each service dimension is consistently negative. The largest difference is that of "competence" with a score of -0.58 , followed by the "reliability" dimension with a gap score of -0.42 and the "responsiveness" dimension of -0.33 . The smallest gap is the "credibility" dimension with a mean score of -0.26 . Thus, improvements are required across all four dimensions. The gap score highlights "competence" as the most important area for improvement that should be considered by accounting firms. The "reliability' dimension with a score of -0.42 ranks as the number two-service quality dimension that needs attention. This finding corroborates the findings by Samson and Parker (1994), and Casadesus et al. (2002) who show a profound gap in the reliability of services offered by professional consultants. This result may suggest that customers of professional services expect consultants who are reliable in delivering the agreed services.

Table 3 lists the mean score of the expectations and perceptions scales and the mean gap score for each of the 13 service quality attributes. In terms of the perceptions of MAS, the mean score of the 13 attributes range from 3.39 (staff of accounting firms are knowledgeable about customers' operations and systems) to 3.88 (staff of accounting firms are always ready to respond), indicating that the respondents generally agree with all the statements. The findings show that the customers of MAS perceive that the staff of accounting firms are always ready to respond, can be trusted and are ethical when providing their services.

In terms of the expectations of MAS, all 13 attributes receive strong importance with the statements ranging from means of 3.88 (ethical accounting staff) to 4.20 (trust in staff of accounting firms) out of a maximum of five. Based on the expectations section (Table 3), customers expect (1) consultants who are experts in their industry and understand their company-specific operations and systems and needs, (2) consultants who are dependable and can be relied upon to provide the service right the first time, and (3) responsive staff of accounting firms that will give prompt service. 
This finding is in agreement with the studies by Behn et al. (1997) and Carcello et al. (1992), which reveal that financial controllers expect the managers and partners of accounting firms to have greater business and industry knowledge. They also cite that controllers also expect faster responses from accounting staff. Generally, the perception scores are consistently lower than the expectation scores for each attribute.

Analysis of the gap scores show that there is a shortfall between customers' perception and expectation for each service quality attribute. The widest difference in the gap scores is for item number 5 - staff of accounting firms are knowledgeable about clients' operations and system (-0.67), followed by staff of accounting firms are knowledgeable about clients' operations $(-0.65)$ under the "competence" dimension. This shows that the widest gap of -0.58 for the competence dimension is influenced by these two attributes. The third widest gap is item number 12 - accounting firms perform service right the first time (-0.49). The fourth widest gap is item number 10 - staff of accounting firms give prompt service to clients $(-0.47)$. The fifth widest gap is item number $11-$ accounting firms' dependability in handling services.

Based on the top five ranking of the gap, two gaps are from the "competence" dimension, two gaps from the "reliability" dimension and one gap from the "responsiveness" dimension. Hence, this suggests that accounting firms have not met the customers' expectations in the three most critical areas, i.e. competence and responsiveness of accounting staff and reliability of accounting firms. The findings also highlight the most critical service quality attributes that require improvement from accounting firms.

Table 3: Mean levels of customers' perceptions and expectations and service gaps for each attribute

\begin{tabular}{|c|c|c|c|c|}
\hline Attributes & $\begin{array}{l}\text { Mean } \\
\text { Perception } \\
\text { (P) }\end{array}$ & $\begin{array}{l}\text { Mean } \\
\text { Expectation } \\
\text { (E) }\end{array}$ & $\begin{array}{l}\text { Service } \\
\text { Gap (P-E) }\end{array}$ & $\begin{array}{l}\text { Ranking } \\
\text { by service } \\
\text { gap }\end{array}$ \\
\hline $\begin{array}{l}\text { Credibility } \\
\text { Trust in staff of accounting firm } \\
\text { Accounting firm protects clients' } \\
\text { interests } \\
\text { Ethical accounting staff } \\
\text { Clients feel safe in dealings }\end{array}$ & $\begin{array}{l}3.82 \\
3.75 \\
3.80 \\
3.76\end{array}$ & $\begin{array}{l}4.20 \\
4.12 \\
3.88 \\
3.96\end{array}$ & $\begin{array}{l}-0.38 \\
0.37 \\
-0.08 \\
-0.20\end{array}$ & $\begin{array}{l}7 \\
8 \\
13 \\
11\end{array}$ \\
\hline $\begin{array}{l}\text { Competence } \\
\text { Staff of accounting firm are } \\
\text { knowledgeable about clients' } \\
\text { operations and systems } \\
\text { Staff of accounting firm are } \\
\text { knowledgeable about clients' } \\
\text { industry } \\
\text { Staff of accounting firm } \\
\text { understand clients' needs }\end{array}$ & $\begin{array}{l}3.39 \\
3.41 \\
3.65\end{array}$ & $\begin{array}{l}4.06 \\
4.06 \\
4.06\end{array}$ & $\begin{array}{l}-0.67 \\
-0.65 \\
-0.41\end{array}$ & $\begin{array}{l}1 \\
2 \\
6\end{array}$ \\
\hline
\end{tabular}




\begin{tabular}{|l|l|l|l|l|}
\hline Responsiveness & & & & \\
Staff of accounting firm are & 3.78 & 4.12 & -0.34 & 9 \\
willing to help clients & 3.88 & 4.06 & -0.18 & 12 \\
Staff of accounting firm are always & 3.53 & 4.00 & -0.47 & 4 \\
ready to respond & & & & \\
Staff of accounting firm give & & & & \\
prompt service to clients & & & & \\
\hline Reliability & & 4.18 & -0.45 & 5 \\
Accounting firm is dependable in \\
handling service & 3.73 & 3.90 & -0.49 & 10 \\
$\begin{array}{l}\text { Accounting firm performs service } \\
\text { right the first time }\end{array}$ & 3.41 & 4.14 & -0.34 & \\
Accounting firm provides services & & & & \\
as promised & & & & \\
\hline
\end{tabular}

The smallest gap for service quality attributes is item number 3 - ethical accounting staff $(-0.08)$, which is primarily due to the lowest expectation and high perception in this attribute. Overall, the results reveal that the MAS offered by accounting firms are not meeting customers' expectations, as is evident by the negative gap score for each attribute.

\subsection{QFD Results}

This section describes the findings of the second stage of the study, that is, to determine the most competitive elements of improvement to meet the expectations of financial controllers on the service quality of MAS (see mean expectation section in Table 3). There are 13 attributes for customers' expectations of service quality, as placed in Figure 1 (denoted as CR) and coded in Table 4. The average category response or importance rating for each customer requirement is identified (see Table 5). From the table, the customer requirements show values for the importance ratings greater than 3.0. This means that all of the stated requirements are important to customers of MAS.

The absolute scores (denoted as AS in Figure 1) were computed for each customer requirement and improvement element (denoted as IE in Figure 1). These elements of improvement were then ranked relatively (denoted as RS in Figure 1). Based on the final relative score (denoted FRS in Figure 1) after considering ease of implementation of each improvement element identified, 
the five highest values of elements of improvement are IE15 (have qualified and experienced staff who have technical expertise), IE29 (respond promptly to clients' requests for information), IE8 (well-defined engagement content), IE1 (provide clients with a detailed programme, which is based on realistic expectations and show how deadlines will be administered) and IE22 (display enthusiasm for the work done for clients) (see Table 6). From the analysis it appears that in order to improve the service quality of MAS, service providers should most emphasize having qualified and experienced staff who are expert in their jobs and respond promptly to clients' requests for information. Accounting firms should also outline a well-defined engagement content between accounting firms and clients with a detailed programme, which is based on realistic expectations and also show how deadlines will be administered. Additionally, staff of accounting firms should display enthusiasm for the work done for clients in order to improve their services.

The service quality of MAS can also be improved by way of assessing and communicating the scope of services(s) up front. This will help accounting firms to allocate sufficient resources (staff and backup resources) for the engagement and offer design solutions and options. Other elements of improvement that should be focused by accounting firms are maintaining complete client confidentiality, and identifying and defining problems and their cost implications to clients as soon as they are encountered.

The interrelationship between the different elements of improvement was determined through a correlation analysis. The correlated pairs with an alpha value of more than 0.60 were identified. These were plotted as (.) on the roof of the matrix or house of quality (see Figure 1). For example, correlation analysis carried out showed that by implementing IE15 (have qualified and experienced staff who have technical expertise -most highest relative score) will have a positive impact on IE6 (training for continuous update on knowledge and skills), IE20 (be aware of, and conform to requisite regulations, e.g. standards and codes) and IE29 (respond promptly to clients' requests for information). Hence, by sending accounting staff for training to continue their professional knowledge and skills, will expose them to the need to be aware of and conform to the requisite regulations, standards or codes that affect them and their clients business. It will also enrich the qualification and expertise of the accounting staff, which will help them to respond quickly to clients' requests for information. 


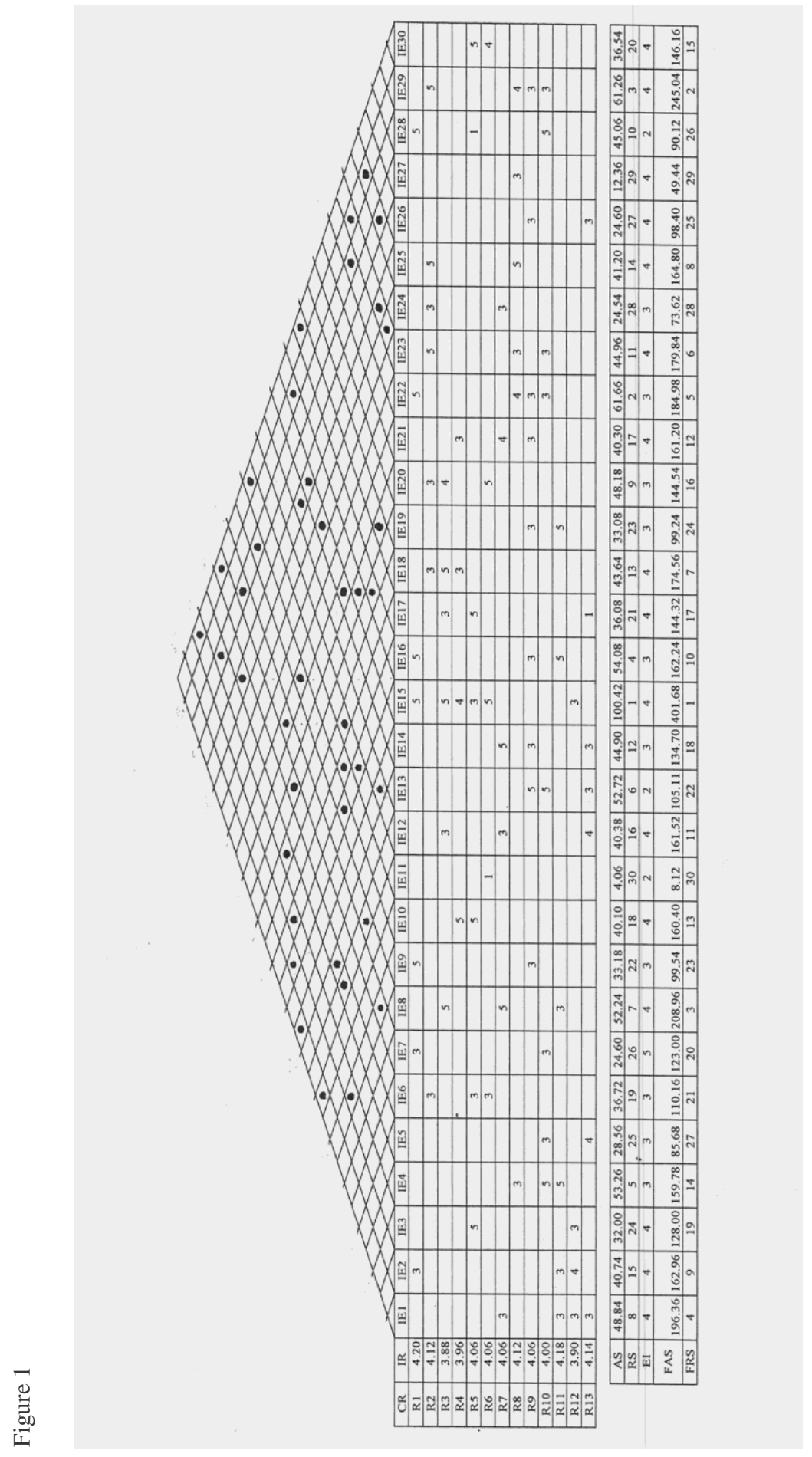




\section{Table 4: Codes and Items}

Codes and items for customer requirements

R1: Trust in staff of accounting firms

R2: Accounting firms protect clients' interests

R3: Accounting staff are ethical

$\mathrm{R} 4$ : Clients feel safe in dealings with accounting firms

R5: Staff of accounting firms are knowledgeable about clients' operations and

systems

R6: Staff of accounting firms are knowledgeable about clients' industry

R7: Staff of accounting firms understand clients' needs

R8: Staff of accounting firms are willing to help clients

R9: Staff of accounting firms are always ready to respond

R10: Staff of accounting firms give prompt service to clients

R11: Accounting firms dependable in handling service

R12: Accounting firms perform service right the first time

R13: Accounting firms provide services as promised
Codes and items for elements of improvement

IE1: Provide clients with a detailed programme, which is based on realistic expectations and show how deadlines will be administered

IE2: Assess and communicate the scope of service(s) up front

IE3: Use computerized system and software, which are compatible with clients' for direct information transfer

IE4: Effective problem solving/complaint handling

IE5: Service expectations should be monitored throughout the engagement

IE6: Training for continuous update on knowledge and skills

IE7: Commence and complete jobs on the scheduled date

IE8: Well defined engagement content

IE9: Well defined channel of communication

IE10: Properly administer jobs through daily vigilance and regular process reviews

IE11: Effective engagement planning/design

IE12: Adherence to engagement content

IE13: Anticipate clients' needs

IE14: Get clients' feedback

IE15: Have qualified and experienced staff who have technical expertise

IE16: Allocate sufficient resources (staff and backup resources)

IE17: Conduct evaluation exercises on accounting staff

IE18: Maintain complete clients' confidentiality

IE19: Ensure personnel assigned to jobs are readily accessible to clients

IE20: Be aware of, and conform to requisite regulations, e.g. standards and codes

IE21: Incorporate specific clients' needs

IE22: Display enthusiasm for the work done for clients

IE23: Identify and define problems and their cost implications to clients as soon as they are encountered

IE24: Provide services which are customized for each individual client, rather than using a standardized

format, i.e. display greater flexibility

IE25: Offer design solutions and options, which reflect refinement and resolution of inconsistencies

IE26: Inform clients of personnel assigned to the various tasks

IE27: Give personalized service

IE28: Ongoing communication with clients

IE29: Respond promptly to clients' requests for information

IE30: Have good understanding of the industry/circumstances (political/financial, etc.) in which clients operate 
Table 5: The Importance Ratings Value for Each Customer Requirement

\begin{tabular}{|l|c|}
\hline Customer Requirements(CRs) & $\begin{array}{c}\text { Importance of } \\
\text { Ratings (IRs) }\end{array}$ \\
\hline R1 - Trust in staff of accounting firms & 4.20 \\
\hline R2 - Accounting firms protect client's' interests & 4.12 \\
\hline R3 - Accounting staff are ethical & 3.88 \\
\hline R4 - Clients feel safe in dealings with accounting firms & 3.96 \\
\hline $\begin{array}{l}\text { R5 - Staff of accounting firms are knowledgeable about clients' operations } \\
\text { and systems }\end{array}$ & 4.06 \\
\hline R6 -Staff of accounting firms are knowledgeable about clients' industry & 4.06 \\
\hline R7 - Staff accounting firms understand clients' needs & 4.06 \\
\hline R8 - Staff of accounting firms are willing to help clients & 4.12 \\
\hline R9 -Staff of accounting firms are always ready to respond & 4.06 \\
\hline R10 - Staff of accounting firms give prompt service to clients & 4.00 \\
\hline R11 - Accounting firms are dependable in handling service & 4.18 \\
\hline R12 - Accounting firms perform service right the first time & 3.90 \\
\hline R13 - Accounting firms provide services as promised & 4.14 \\
\hline
\end{tabular}

Table 6 outlines the five highest values of relationship between the elements of improvement and customer requirements. The implementation of the elements of improvement not only fulfils one of the many customers' requirements. It also fulfils other requirements. For example, when a proposed suggestion, IE15 is implemented, R1, R3, R4, R5, R6 and R12 are then filled. The results suggest that the most important improvement for service providers to be competitive is to have qualified and experienced staff who are expert in their work. By implementing this improvement element, the service provider could fulfil various customer requirements: R1 - trust in staff of accounting firms (strong relationship), R3 - accounting staff are ethical (strong relationship) and R4 - clients feel safe in dealings with accounting firms (moderate to strong relationship). In addition, IE15 is also able to meet R5 - staff of accounting firms are knowledgeable about clients' operations and systems (moderate relationship), R6 - staff of accounting firms are knowledgeable about clients' industry (strong relationship) and R12 - accounting firms perform service right the first time (moderate relationship). The second improvement element that should be considered by service providers is IE29respond promptly to clients' requests for information. By implementing IE29, service providers would be directly able to meet all service quality requirements in the responsiveness dimension, including $\mathrm{R} 8$ (staff of accounting firms willing to help clients), R9 (staff of accounting firms always ready to respond) and R10 (staff of accounting firms give prompt service to clients). Indirectly, it also shows that accounting firms are protecting clients' interests (R2) throughout the engagement by being responsive to clients. The third improvement element that should be 
focused on by accounting firms is a well-defined engagement content outline between them and the clients (IE8). By having detailed and clear agreements between them it should be able to meet R7 (staff of accounting firms understand clients' needs), R11 (accounting firms are dependable in handling services) and R3 (accounting staff are ethical). Overall, the results suggest that the IE15 was identified as being the minimum improvement that would be able to meet various customer requirements while considering its ease of implementation. This improvement is the most competitive suggestion for improvement of service quality in MAS. Generally, the five highest elements of improvement should be able to meet the five highest importance service qualities that the customers expect of MAS.

Table 6: Five Highest Improvement Elements and Customer Requirements

\begin{tabular}{|c|c|}
\hline Elements of improvement & Customer Requirements \\
\hline $\begin{array}{l}\text { IE15 (Accounting firms have expert, } \\
\text { qualified and experienced staff) }\end{array}$ & $\begin{array}{l}\text { R1 (Trust in staff of accounting firms) } \\
\text { R3(Accounting staff are ethical) } \\
\text { R4(Clients feel safe in dealings with accounting firms) } \\
\text { R5(Staff of accounting firms are knowledgeable about } \\
\text { clients' operations and systems } \\
\text { R6(Staff of accounting firms are knowledgeable about } \\
\text { clients' industry) } \\
\text { R12(Accounting firms perform service right the first time) }\end{array}$ \\
\hline $\begin{array}{l}\text { IE29 (Respond promptly to clients' } \\
\text { requests for information) }\end{array}$ & $\begin{array}{l}\text { R2(Accounting firms protect clients' interests } \\
\text { R8 (Staff of accounting firms are willing to help clients) } \\
\text { R9 (Staff of accounting firms are always ready to respond) } \\
\text { R10 (Staff of accounting firms give prompt service to } \\
\text { clients) }\end{array}$ \\
\hline $\begin{array}{l}\text { IE8 (Well-defined engagement } \\
\text { content outline between accounting } \\
\text { firms and clients) }\end{array}$ & $\begin{array}{l}\text { R3(Accounting staff are ethical) } \\
\text { R7(Staff accounting firms understand clients' needs) } \\
\text { R11(Accounting firms dependable in handling service) }\end{array}$ \\
\hline $\begin{array}{l}\text { IE1 (Provide clients with a detailed } \\
\text { programme, which is based on } \\
\text { realistic expectations and show how } \\
\text { deadlines will be administered) }\end{array}$ & $\begin{array}{l}\text { R7(Staff accounting firms understand clients' needs) } \\
\text { R11(Accounting firms dependable in handling service) } \\
\text { R12(Accounting firms perform service right the first time) } \\
\text { R13(Accounting firms provide services as promised) }\end{array}$ \\
\hline $\begin{array}{l}\text { IE22 (Display enthusiasm for the } \\
\text { work done for clients) }\end{array}$ & $\begin{array}{l}\text { R1(Trust in staff of accounting firms) } \\
\text { R8(Staff of accounting firms are willing to help clients) } \\
\text { R9(Staff of accounting firms are always ready to respond) } \\
\text { R10(Staff of accounting firms give prompt service to } \\
\text { clients) }\end{array}$ \\
\hline
\end{tabular}

\section{Conclusion}

The present study provides valuable insights for accounting firms into the aspects of service quality that are most valued by customers. This study is important and relevant because accounting firms need to be prepared for the effects of an ever-changing business environment. The results of this study provide several 
contributions to the existing literature, as this is among the first empirical studies in assessing service quality through gap analysis in MAS in Malaysia. The gap score derived from the perceptions and expectations of customers highlights the service quality dimensions and attributes that meet or exceed customers' expectations. Generally, the findings from this study reveal that accounting firms do not meet all the service quality dimensions and the most critical area that should be focused on by them is competency of staff in rendering their services and the reliability of accounting firms in providing advisory services. Therefore, the gap analysis highlights the areas of weaknesses that should be focused on by accounting firms. In terms of attributes of service quality of MAS, knowledge of accounting staff in clients' operations and systems and knowledge on clients' industry were found to be the greatest gap. Hence, accounting firms should focus their efforts on improving accounting staff weaknesses in these areas.

The application of QFD has demonstrated a practical process that allows accounting firms to become customer and quality oriented to improve their current services. The QFD provides a systematic way in meeting customer service quality expectations. In addition, critical elements of improvement of service delivery can now be identified more effectively by mean of tools to correlate the service quality expectations of financial controllers and service design of the accounting firms. This study identifies the elements of improvement that should be emphasized most by accounting firms: expert, qualified and experienced staff, staff who respond promptly to clients' requests for information, and accounting staff should display enthusiasm for the work done for clients. In addition, accounting firms should outline a well-defined engagement content between them and clients and provide clients with a detailed programme, which is based on realistic expectations and show how deadlines should be administered. Priority should be given to provide accounting staff who are expert, qualified and experienced, in that it covered almost half of thirteen service quality attributes required by clients. It can be a starting point that can be considered when improving the service quality of MAS.

Similar to most research, this study also has limitations. Due to the low response, the study might not cover all the service quality attributes expected by clients. Consequently, the current study might not be representative of the clients of MAS for the whole of Malaysia. If the scope is broadened, wider views and different results might be obtained. Future research may want to consider other dimensions or attributes that constitute service quality in MAS.

\section{References}

Abili, K., Thani, F.N. and Afarinandehbin, M. (2012). Measuring Service Quality by means of SERVQUAL method. Asian Journal on Quality. Vol. 13, No. 3, 204-211. 
Aldhizer, G.R. III, Turner, L.D. and Shank, M.D. (2002). Determinants of Consulting Service Quality for Accounting and Non-accounting Service Provider. Journal of Information System. Vol. 16, No. 1, 61-74.

Andronikidis, A., Georgiou, A.C., Gotzamani, K. and Kamvysi, K (2009).

The Application of Quality Function Deployment in Service Quality Management. The TQM Journal. Vol. 21, No. 4, 319-333.

Asohan, S. (2002). K.Accountants-A Human Resource Perspective. Akauntan Nasional. (December): 41-43.

Baki, B., Basfirinci, C.S., Cilingir, Z. and Murat, I (2009). An Application of Integrating SERVQUAL and Kano's Model into QFD for logistics Services. A Case Study from Turkey. Asia Pacific Journal of Marketing and Logistics. Vol. 21, No. 1, 106-126.

Baldwin, A. and Sohal, A. (2003). Service Quality Factors and Outcomes in Dental Care. Managing Service Quality. Vol. 3, No. 3, 197-206.

Ballantyne, D., Christopher, M. and Payne, A. (1995). Improving the Quality of Services Marketing: Service Re(design) is the Critical Link. Journal of Marketing Management. Vol. 11, 7-24.

Behn, B.K., Carcello, J.V., Hermanson, D.R. and Hermanson, R.H. (1997). The Determinants of Audit Client Satisfaction Among Clients of Big 6 Firms. Accounting Horizons. Vol. 11, No. 1, 7-24.

Briloff, A.J. (1994). Our Profession's "Jurassic Park". The CPA Journal. Vol. 64, No, 8, 26.

Brysland, A. and Curry, A. (2001). Service Improvements in Public Services Using SERVQUAL. Managing Service Quality. Vol. 11, No. 6, 389-401.

Burns, A. C. and Bush, R. F. (2000). Marketing Research. Englewood Cliffs, NJ: Prentice-Hall Inc.

Cameran, M., Moizer, P. and Pettinicchio, A. (2010). Customer Satisfaction, Corporate Image, and Service Quality in Professional Services. The Service Industries Journal. Vol. 30, No. 3, 421-435.

Carcello, J.V., Hermanson, R.H. and McGrath, N.T. (1992). Audit Quality Attributes: The Perceptions of Audit Partners, Prepares, and Financial Statement Users. Auditing: A Journal of Practice \& Theory (Spring). Vol. 11, No. 1, 1-15.

Casadesus, M., Viadiu, F.M. and Saizarbitoria, I.H. (2002). Quality Service of ISO 9000 Consultants. International Journal of Quality \& Reliability Management. Vol. 19, No. 8/9, 998-1013.

Cronbach, L.J. (1951). Coefficient Alpha and the Internal Structure of Tests. Psychometrica. Vol. 16, 297-334.

Curry, A. (1999). Innovation in Public Service Management. Managing Service Quality. Vol. 9, No. 3, 180-190.

Foong, S.Y. Liberalization of the Accounting Services Sector: Perceived Impact and Challenges for Accountants in Malaysia, Akauntan Nasional, May, 2002. pp.7-15. 
Guinta, L. and Praizler, N.C. (1993). The QFD Book: The Team Approach to Solving Problems and Satisfying Customers Through QFD. New York, U.S.A: American Management Association (AMACOM).

Hauser, J.R. and Clausing, D. The House of Quality. Harvard Business Review. May-June, 1998, pp.63-73.

Houston, R.W., Peters, M.F. and Pratt, J.H. (2005). Non-litigation Risk and Pricing Audit Services. Auditing: A Journal of Practice and Theory. Vol. 24, No. 1, 37-53.

Hwarng, H.B. and Teo, C. (2001). Translating Customers' Voices into Operations Requirements. A QFD Application in Higher Education. International Journal of Quality \& Reliability Management. Vol. 18, No. 2, 195-225.

Ismail, I., Haron, H., Ibrahim, D.N. and Isa, S.M (2006). Service Quality, Client Satisfaction and Loyalty towards Audit Firms. Managerial Auditing Journal. Vol. 21, No. 7, 738-756.

Jeong, M. and Oh, H. (1998). Quality Function Deployment: An Extended Framework for Service Quality and Customer Satisfaction in the Hospital Industry. Hospitality Management. Vol. 17, 375-390.

Kim, K., Park, K. and Seo, S. (1997). A Matrix Approach for Telecommunication Technology Selection. Computer and Engineering. Vol. 33, No. 3/4, 833836.

Lee, H., Lee, Y. and Yoo, D. (2000). The Determinants of Perceived Service Quality and its Relationship with Satisfaction. Journal of Services Marketing. Vol. 14, No. 3, 217-231.

McKell, L.J. and Stocks, K.D. (1987). Management Advisory Services-Trends and Projections. The CPA Journal. Vol. 57, No. 7, 84-85.

Parasuraman, A., Zeithaml, V.A. and Berry, L.L. (1985). A Conceptual Model of Service Quality and its Implications for Future Research. Journal of Marketing. (Fall), Vol. 49, 41-50.

Parasuraman, A., Zeithaml, V.A. and Berry, L.L. (1988). SERVQUAL: A Multiple-Item Scale for Measuring Consumer Perceptions of Service Quality. Journal of Retailing. Vol. 64, No. 1, 12-40.

Parasuraman, A., Zeithaml, V.A. and Berry, L.L. (1991). Refinement and Reassessment of the SERVQUAL Scale. Journal of Retailing. Vol. 67, No. 4, 420-450.

Radharamanan, R. and Godoy, L. P. (1996). Quality Function Deployment as Applied to a Health Care System. Computers Industrial Engineering. Vol. 31, 443-446.

Sahney, S., Banwet, D.K. and Karunes, S. (2003). Enhancing quality in education: application of quality function deployment - an industry perspective. Work Study. Vol. 52, No. 6, 297-309.

Samson, D. and Parker, R. (1994). Service Quality: The Gap in the Australian Consulting Engineering Industry. International Journal of Quality \& Reliability Management. Vol. 11, No. 7, 60-76. 
Teoh, H.Y. and Lim, C.C. (1996). An Empirical Study of the Effects of Audit Committees, Disclosure of Non-audit Fees, and Other Issues on Audit Independence: Malaysia Evidence. Journal of International Accounting, Auditing \&Taxation. Vol. 5, No. 2, 231-248.

Thompson, J.H., Hodge, T.G. and A. Hoskins, M. Audit Services: Still Part of the Mix?. The National Public Accountant, 1997, Vol. 42, No. 5, pp.12-14.

Türk, Z. and Avcilar, M.Y. (2009). The Effects of Perceived Service Quality of Audit Firms on Satisfaction and Behavioural Intensions: A Research on the Istanbul Stock Exchange Listed Companies. Research Journal of Business Management. Vol. 2, No. 1, 1819-1932.

Turner L.D., Aldhizer, G.R. III and Shank, M.D. (1999). Client Perceptions of MAS As Measured By A Marketing-Based Service Quality Model. Accounting Horizons. Vol. 13, No. 1, 17-36.

Weekes, D.J., Scott, M.E. and Tidwell, P.M. (1996). Measuring quality and client satisfaction in professional business services. Journal of Professional Services Marketing. Vol. 14, No. 2, 25-37.

Welsh, J.F. and Dey, S. (2002). Quality Measurement and Quality Assurance in Higher Education. Quality Assurance in Education. Vol. 10, No. 1, 23-25.

Yeşilada, F.A. and Yurdakul, D. (2009). Improving Healthcare Service Quality: An Application of Integrating SERVQUAL and Kano Model into Quality Function Deployment. International Journal of Business Research. Vol. 9, No. 7, 156-165. 